\title{
Antioxidant activity and compound constituents of gamma-irradiated black rice (Oryza sativa L.) var. Cempo Ireng indigenous of Indonesia
}

\author{
VENTY SURYANTI $^{1, \boldsymbol{\nu}}$, RIYATUN ${ }^{2}$, SUHARYANA $^{2}$, SUTARNO $^{3}$, OZI ADI SAPUTRA $^{1}$ \\ ${ }^{1}$ Department of Chemistry, Faculty of Mathematics and Natural Sciences, Universitas Sebelas Maret. J1. Ir. Sutami 36A Surakarta 57126, Central Java, \\ Indonesia. Tel./fax.: +62-271-663375, ^email: venty@mipa.uns.ac.id \\ ${ }^{2}$ Department of Physics, Faculty of Mathematics and Natural Sciences, Universitas Sebelas Maret. Jl. Ir. Sutami 36A Surakarta 57126, Central Java, \\ Indonesia \\ ${ }^{3}$ Department of Biology, Faculty of Mathematics and Natural Sciences, Universitas Sebelas Maret. Jl. Ir. Sutami 36A Surakarta 57126, Central Java, \\ Indonesia
}

Manuscript received: 27 May 2020. Revision accepted: 21 August 2020.

\begin{abstract}
Suryanti V, Riyatun, Suharyana, Sutarno, Saputra OA. 2020. Antioxidant activity and compound constituents of gammairradiated black rice (Oryza sativa L.) var. Cempo Ireng Indigenous of Indonesia. Biodiversitas 21: 4205-4212. Nowadays, black rice is gaining consumer interest because of its health benefit. Due to the high content of antioxidant compounds such as phenolics and flavonoids, the nutritional profile of black rice is much better than any other rice varieties. Anthocyanins, pigment with powerful antioxidant properties, give a vibrant color to the rice. The antioxidant activity and chemical constituents of the non-irradiated and gamma-irradiated black rice Oryza sativa L. var Cempo Ireng were investigated. The total phenolic content was determined based on the reaction of the Folin-Ciocalteu reagent with samples. Total anthocyanin was determined by the $\mathrm{pH}$ differential method. Antioxidant activity was fulfilled using DPPH method. The results revealed that non-irradiated and gamma-irradiated black rice were categorized as potent antioxidants. It is noted that irradiation increased antioxidant activity and changed the chemical components of black rice. Both of non-irradiated and irradiated black rice contains simple phenolics and flavonoids, including anthocyanins. Non-irradiated and irradiated black rice possess similar types of secondary metabolites, with different chemical content. The non-irradiated black rice contains anthocyanins of cyanidin-3-O-glucoside, whereas the irradiated black rice possesses anthocyanin of peonidin-3-O-glucoside. Additionally, irradiated black rice contains terpenoids, which increased its antioxidant activity compared to the control.
\end{abstract}

Keywords: Antioxidant activity, irradiated black rice, Oryza sativa, total anthocyanins, total phenolics

\section{INTRODUCTION}

Rice (Oryza sativa L.) is consumed by nearly half of the world's population and considered one of the most important cereal crops. Black rice, a pigmented rice, is becoming more popular as a functional food (Pratiwi and Purwesti 2017). Black rice consumption inhibits the cancer cell invasion, prevents cardiovascular disease, and reduces the risk of fatty liver diseases, diabetes, and obesity (Pratiwi et al. 2015; Rathna Priya et al. 2019; Rukmana et al. 2016). The health benefits of black rice are associated with its nutritional values and antioxidant components $(\mathrm{Hu}$ 2003; Zhang et al. 2010; Bolea et al. 2016; Suttiarporn et al. 2016; Batubara et al. 2017). Black rice has a high content of fat, protein, and crude fiber. It also contains phenolic compounds, such as p-coumaric acid, caffeine acid, and ferulic acid, protocatechuic acid, vanillic acid, and hydroxyl benzoic acid, which are responsible for the antioxidant activity (Walters and Marchesan 2011). Furthermore, black rice contains flavonoids, including anthocyanins, which play an important role in antioxidant activity (Seo et al. 2011). Cyanidin-3-O-glucoside and peonidin-3-O-glucoside are anthocyanins usually found in black rice (Figure 1). Cyanidin-3-O-glucoside is the main anthocyanins, forming to $94 \%$ of the total anthocyanins content (Chen et al. 2012; Hou et al. 2013; Hao et al. 2015; Apridamayan et al. 2017). The color of black rice is caused by anthocyanin pigments (Park et al. 2008; Lee 2010; Loypimai et al. 2016). Nowadays, phenolic- and flavonoidrich natural food have gained interest in nutrition and food science (He and Giusti 2010; Cisowska et al. 2011). These compounds possess aromatic rings having at least one hydroxyl group that can act as electron donors. Their hydroxyl group can directly engage in antioxidant action (Walter and Marchesan 2011; Khoo et al. 2017; Suryanti et al. 2020)<smiles></smiles>

$$
\begin{array}{ll}
\mathrm{R}=\mathrm{OH} & \text { Cyanidin-3-O-glucoside } \\
\mathrm{R}=\mathrm{OCH}_{3} & \text { Peonidin-3-O-glucoside }
\end{array}
$$

Figure 1. Structure of cyanidin-3-O-glucoside and peonidin-3-Oglucoside 
The cultivation of black rice is very rare due to its plant height, sensitivity to the natural enemy, long harvest period, and low productivity. A mutation is often used to overcome the limitation of the crops (Harding et al. 2012; El-Degwy 2013; Marcu et al. 2013; Shao et al. 2013). It has been reported that mutation induction through irradiation improves the quality of local black rice cultivar (Hartanti et al. 2017). The grains of black rice var. Cempo Ireng irradiated with gamma-ray at a dose of 200 and $300 \mathrm{~Gy}$, namely BR-200 and BR-300 results in shorten harvesting time, reduce plant height, and enhanced stress tolerance (Patmi et al. 2008). It also changes the anthocyanin content of the wild variety of black rice (Purwanto et al. 2019). However, the nutrient content, i.e. moisture, lipids, proteins, carbohydrates, and fibers contents in gammairradiated black rice var. Cempo Ireng was not significantly different from non-irradiated rice.

The nutritional value of BR-200 was slightly better than that of BR-300 (Riyatun et al. 2017). Although the antioxidant activity and chemical compounds of the black rice have been reported, studies on the antioxidant activity and chemical compounds of irradiated black rice are still limited. Therefore, this paper describes the antioxidant activity and chemical compound diversities of irradiated black rice in comparison to non-irradiated variety.

\section{MATERIALS AND METHODS}

\section{Materials}

Non-irradiated black rice (BR-NI) and irradiated black rice (Oryza sativa L. cv. Cempo Ireng) were used in this research. The irradiated black rice used in this study was the third generation of gamma-irradiated black rice with doses 200 and 300 Gy (BR-200 and BR-300). 2,2diphenyl-(1-picrylhydrazyl) (DPPH) and gallic acid were purchased from Sigma Aldrich. Other analytical grade chemicals were obtained from E-Merck and used without further purification.

\section{Sample preparation}

Black rice grains $(200 \mathrm{~g})$ were grounded into a fine powder and macerated three times with ethanol at room temperature for $24 \mathrm{~h}$. The filtrate was collected and evaporated using a rotary evaporator to get concentrated extracts.

\section{Gas Chromatography-Mass Spectroscopy (GC-MS)}

The ethanol extract of BR-NI and BR-200 was analyzed by Shimadzu QP2010S GC-MS. The GC-MS was run using EI $70 \mathrm{Ev}$ ionizing type, Rtx $5 \mathrm{Ms}$ column $(30 \mathrm{~m}$ length $\times 0.25 \mathrm{~mm} \mathrm{ID),} \mathrm{injector} \mathrm{temperature} \mathrm{of} 300^{\circ} \mathrm{C}$, column temperature of $70^{\circ} \mathrm{C}$, splitless injection method, detector temperature of $300^{\circ} \mathrm{C}$ and the carrier gas was $\mathrm{He}$ with the operating pressure of $13.7 \mathrm{kPa}$.

\section{Liquid Chromatography-Mass Spectrometry (LC-MS)}

The ethanol extract of BR-NI and BR-200 was analyzed by LC-MS Waters 2489 with a UV-Vis detector. The column temperature was $35^{\circ} \mathrm{C}$ and the solvent used was a mixture of solution A (aqua dest: formic acid = 9:1) and solution B (aquabidest: acetonitrile: formic acid $=6: 3: 1$ ) with a flow rate of $1 \mathrm{~mL} / \mathrm{min}$ for $25 \mathrm{mins}$. The solvents gradient used for the initial 5 mins was $75 \%$ solution A and $25 \%$ solution $\mathrm{B}$, the second 5 mins were $71 \%$ solution $\mathrm{A}$ and $29 \%$ solution $\mathrm{B}$, the third 5 mins was $66 \%$ solution $\mathrm{A}$ and $34 \%$ solution $\mathrm{B}$, the fourth 5 mins was $62 \%$ solution $\mathrm{A}$ and $38 \%$ solution $\mathrm{B}, 57 \% \mathrm{~A}$ and $43 \%$ solution $\mathrm{B}$, the last 5 mins was $100 \%$ solution B. Their absorbance was measured at $520 \mathrm{~nm}$. MS analysis was used ESI ionization.

\section{Determination of total phenolics}

The total phenolics were analyzed by a modified method of Doymaz and Karasu (2018). In $5 \mathrm{~mL}$ volumetric flask, gallic acid (100 ppm, $1 \mathrm{~mL})$ was mixed with FolinCiocalteu reagent $(0.5 \mathrm{~mL})$ and left for 1 minute. Four $\mathrm{ml}$ of $7.5 \% \mathrm{Na}_{2} \mathrm{CO}_{3}$ solution was added to the mixture and left for a further 1 minute. The samples were analyzed using UV-Vis Spectroscopy (Perkin Elmer Precisely Lambda 25 $\mathrm{UV}-\mathrm{Vis}$ ) at 10-minute intervals until reaching equilibrium state. The same procedure was applied for obtaining the standard curves of gallic acid with concentrations of 25, 50, $75,100 \mathrm{ppm}$. The ethanol extract of black rice (100 ppm) was analyzed for total phenolics content. Total phenolics were quantified using formula (1), where $\mathrm{C}$ is gallic acid concentration determined from the calibration curve $(\mathrm{g} / \mathrm{L})$, $\mathrm{V}$ is the volume of sample extract $(\mathrm{L})$ and $\mathrm{m}$ is the weight of the sample extract $(\mathrm{K})$. Total phenolics are expressed as milligram of gallic acid equivalents (GAE) per gram of dry.

$$
\text { Phenolics Total }(\mathrm{g} \text { GAE } / \mathrm{Kg})=\frac{\mathrm{C} . \mathrm{V}}{\mathrm{m}}
$$

\section{Determination of total anthocyanins}

The determination of anthocyanin content was carried out using the pH-differential method (AOAC 2005-02). Ethanol extract $(0.05 \mathrm{~g})$ was put into a tube and added with $4 \mathrm{~mL}$ of $\mathrm{KCl}$ buffer solution ( $\mathrm{pH} 1)$ and $4 \mathrm{~mL}$ of $\mathrm{CH}_{3} \mathrm{COONa}$ buffer solution ( $\mathrm{pH} 4.5$ ). After 2 hours, the samples were filtered and their absorbance was measured at $520 \mathrm{~nm}$ and $700 \mathrm{~nm}$ wavelengths using UV-Vis Spectroscopy (Perkin Elmer Precisely Lambda 25 UVVis).

The anthocyanin content was calculated using formula 2 , where $A$ is $\left(\mathrm{A}_{520}-\mathrm{A}_{700}\right)_{\mathrm{pH} 1}-\left(\mathrm{A}_{520}-\mathrm{A}_{700}\right)_{\mathrm{pH} 4,5}, \varepsilon$ is the molar extinction of cyanidin-3-O-glucoside $\left(26.900 \mathrm{~L} \cdot \mathrm{mol}^{-1} . \mathrm{cm}^{-}\right.$ $\left.{ }^{1}\right)$, I is cuvette thickness $(1 \mathrm{~cm}), \mathrm{Mw}$ is the molecular weight of cyanidin-3-O-glucoside (449.2 $\mathrm{g} / \mathrm{mol}), \mathrm{DF}$ is dilution factor, $\mathrm{V}$ is the volume of sample extract, $\mathrm{W}$ is the weight of sample extract.

$$
T A=\frac{A}{s \times I} \times M w \times D F \times \frac{V}{W} \times 100 \% \ldots \ldots \ldots
$$

Cyanidin-3-O-glucoside, the most common pigment in nature, is selected as a standard for the evaluation of total anthocyanins contents.

\section{Determination of antioxidant activity}

The antioxidant activity was determined using DPPH scavenging radical activity by following the method of 
Salazar-Aranda et al. (2011). The stock solution (100 ppm) was diluted to the concentrations of $12.5,25,50,75$, and $100 \mathrm{ppm}$ in a $5 \mathrm{~mL}$ volumetric flask. Vitamin $\mathrm{E}$ concentrations $(2.5,5,10,12.5$, and $20 \mathrm{ppm})$ was used as a positive control. One $\mathrm{mL}$ of DPPH solution in methanol (100 ppm) was added to the mixture and was left for 30 minutes in a dark condition. The mixture was then analyzed at the $\lambda_{\max }$ wavelength. The $\lambda_{\max }$ wavelength was obtained previously by measuring the DPPH solution (100 ppm) at a wavelength of 800-400 nm. Antioxidant activity was assessed using formula (3), where $\mathrm{A}$ is the absorbance of ethanol as the black and B is the absorbance of the sample. The correlation between each concentration and its percentage of scavenging was plotted and the $\mathrm{IC}_{50}$ was calculated by interpolation. The $\mathrm{IC}_{50}$ value represents the concentration of antioxidants to inhibit $50 \%$ of free radicals.

$$
\text { Antioxidant Activity }=\frac{\overline{(A-B)}}{A} \times 100
$$

\section{RESULTS AND DISCUSSION}

The ethanol extract of black rice grain was obtained in $14-15 \%$ yield as a viscous yellow oil. These extracts were analyzed for total phenolic and total anthocyanin contents (Table 1). The total phenolic content determination was performed based on the reaction of the Folin-Ciocalteu reagent with samples. The resulting blue-colored solution intensity is proportional to the amount of phenolics present. Total anthocyanin is determined based on changes in anthocyanin structure at $\mathrm{pH} 1$ and $\mathrm{pH} 4.5$. The difference in absorbance between the two buffer solutions is due to the total content of monomeric anthocyanin pigments. The non-enzymatic brown pigments and polymerized anthocyanin pigments are omitted from the absorbance calculation. They do not show reversible structural transformation as a function of $\mathrm{pH}$.

Antioxidant activity of the extracts was determined using DPPH method. DPPH radical is widely used as a substrate for evaluating antioxidant activity because DPPH is stable radical, and its simplicity testing and accuracy.
The color changes of DPPH solution from purple to yellow is observed when the radical is quenched by antioxidant. The DPPH radical scavenging activities of vitamin $\mathrm{E}$ and black rice are presented in Figure 2 . The $\mathrm{IC}_{50}$ values were presented in Table 2. The lower the $\mathrm{IC}_{50}$ value, the better the antioxidant activity. The radical scavenging capacity of the black rice extracts exhibited concentration-dependent.

Tabel 1. Total phenolics and total anthocyanins content of the black rice extracts

\begin{tabular}{ccc}
\hline Samples & $\begin{array}{c}\text { Total phenolics } \\
\text { content } \\
\text { (mg GAE/g) }\end{array}$ & $\begin{array}{c}\text { Total anthocyanins content } \\
\text { (g Cyanidin-3- } \boldsymbol{O}- \\
\text { glucoside/kg) }\end{array}$ \\
\hline BR-NI & $100.47 \pm 0.11$ & $4.729 \pm 0.023$ \\
BR-200 & $87.15 \pm 0.51$ & $1.956 \pm 0.105$ \\
BR-300 & $73.82 \pm 0.25$ & $3.740 \pm 0.092$ \\
\hline
\end{tabular}

Table 2. $\mathrm{IC}_{50}$ values of vitamin $\mathrm{E}$ and black rice

\begin{tabular}{ccc}
\hline Sample & IC50 $(\mathbf{p p m})$ & Antioxidant activity \\
\hline BR-NI & 47.99 & Very strong \\
BR-200 & 32.67 & Very strong \\
BR-300 & 43.53 & Very strong \\
Vitamin E & 3.53 & Very strong \\
\hline
\end{tabular}

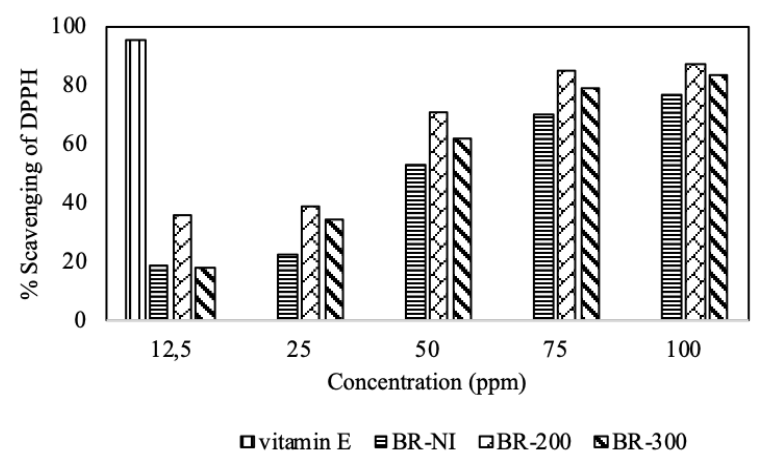

Figure 2. DPPH free radical scavenging activity of vitamin $\mathrm{E}$ and black rice extracts in different concentrations

Tabel 3. Chemical composition of non-irradiated black rice BR-NI and $3^{\text {rd }}$ generation of gamma-irradiated black rice by GC-MS

\begin{tabular}{|c|c|c|c|c|c|}
\hline \multicolumn{3}{|r|}{ BR-NI } & \multicolumn{3}{|r|}{ BR-200 } \\
\hline $\mathbf{R t}$ & $\%$ & Compound & Rt & $\%$ & Compound \\
\hline- & - & 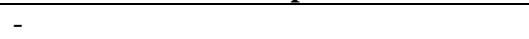 & 16.375 & 5.08 & Geyrene \\
\hline- & - & - & 25.775 & 1.94 & Caryophyllene \\
\hline- & - & - & 25.233 & 1.73 & Selinene \\
\hline- & - & - & 27.467 & 2.04 & Cadinene \\
\hline- & - & - & 28.925 & 1.73 & Decanoic acid \\
\hline 37.007 & 13.08 & Hexadecanoic acid & 36.974 & 23.55 & Hexadecanoic acid \\
\hline 40.605 & 54.86 & 9,12-Octadecadienoic acid & 40.510 & 15.74 & 9,12-Octadecadienoic acid \\
\hline 44.133 & 10.50 & 2-Methyl-, 2-(dimethylamino)ethyl ester & 44.014 & 10.21 & 2-Methyl-, 2-(dimethylamino)ethyl ester \\
\hline 47.166 & 17.03 & Cyclohexane ethanamine & 47.079 & 9.24 & Cyclohexane ethanamine \\
\hline
\end{tabular}




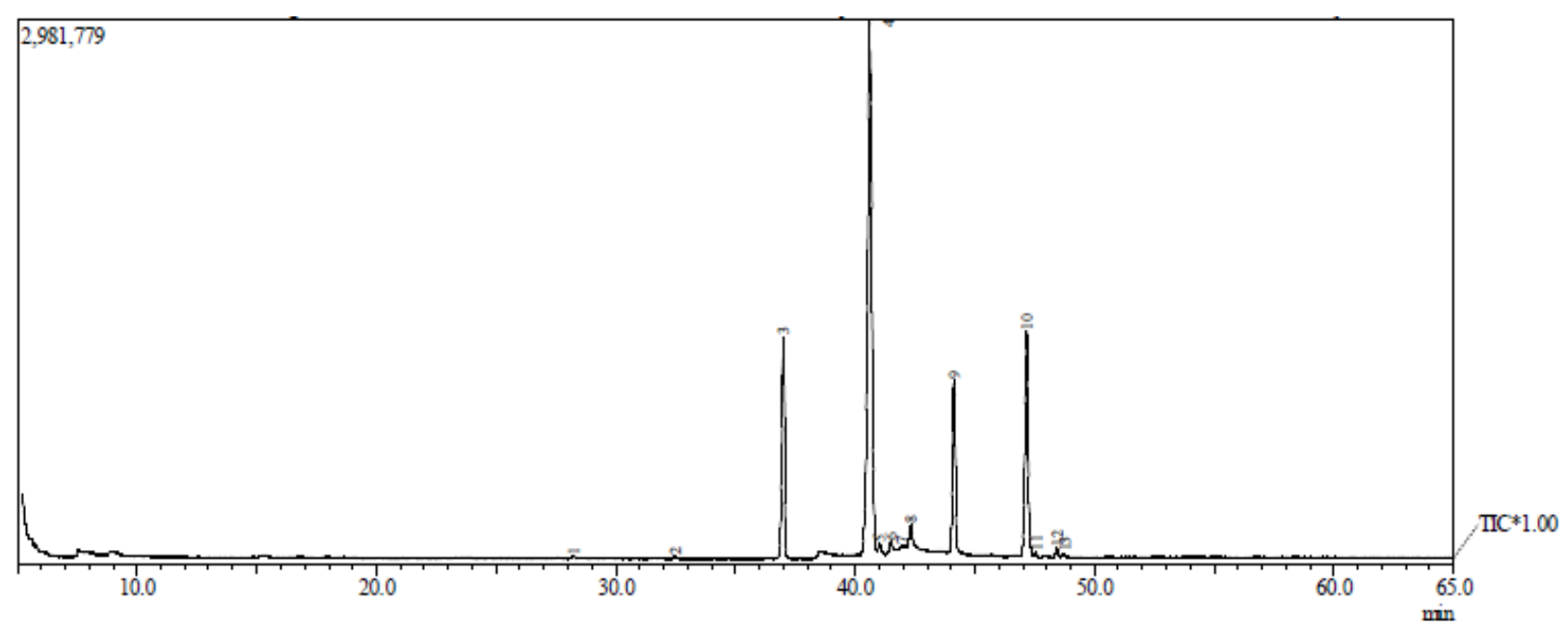

Figure 3. GC chromatogram of ethanolic extract of nonirradiated black rice BR-NI

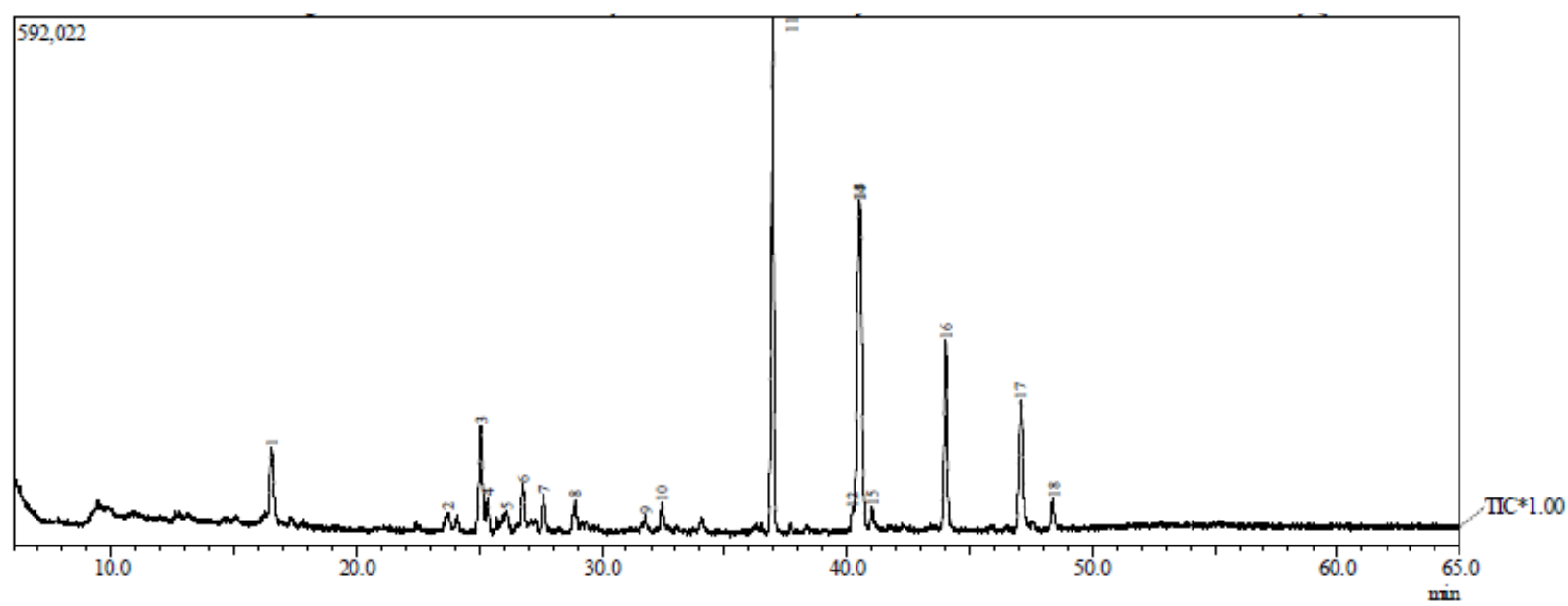

Figure 4. GC chromatogram of ethanolic extract of $3^{\text {rd }}$ generation of gamma-irradiated black rice BR-200

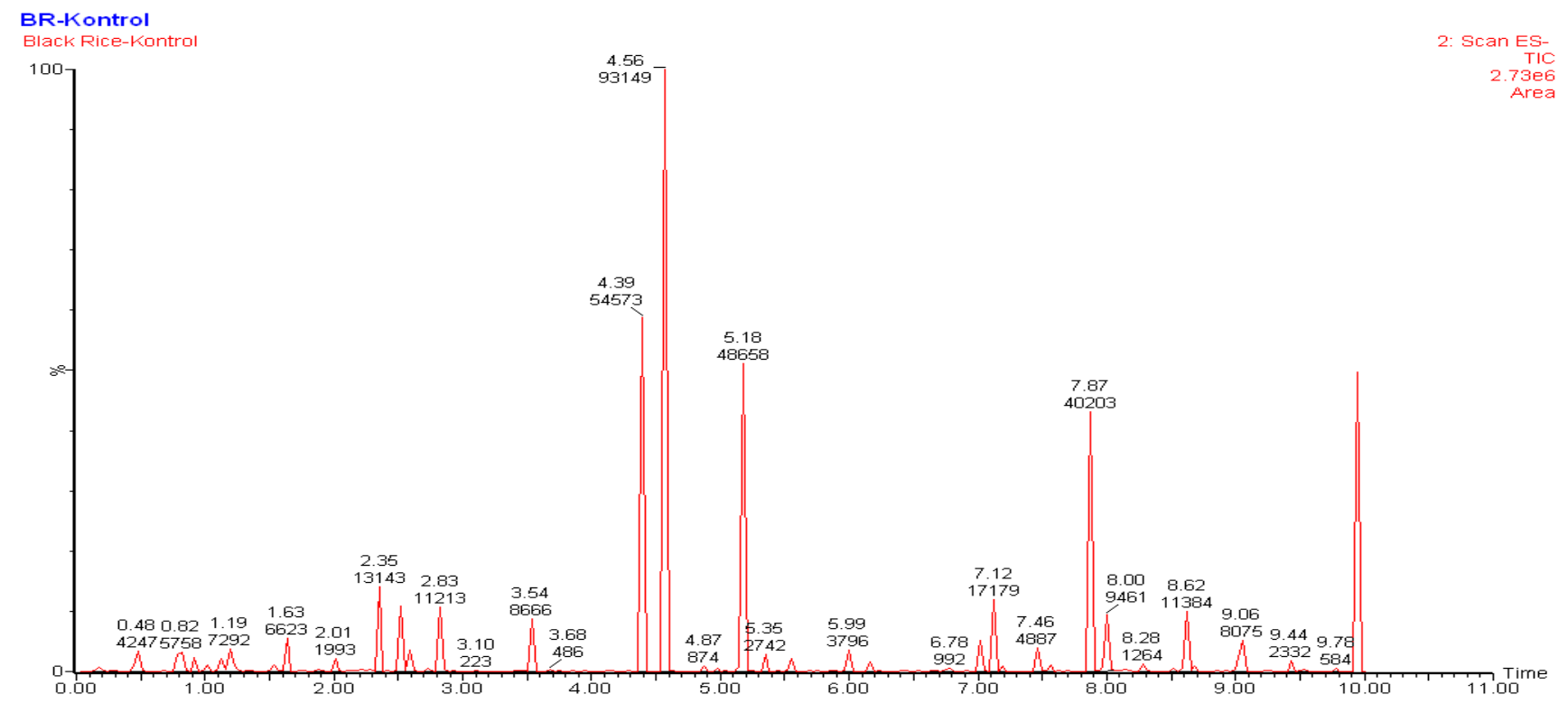

Figure 5. LC-MS chromatogram of non-irradiated black rice BR-NI 


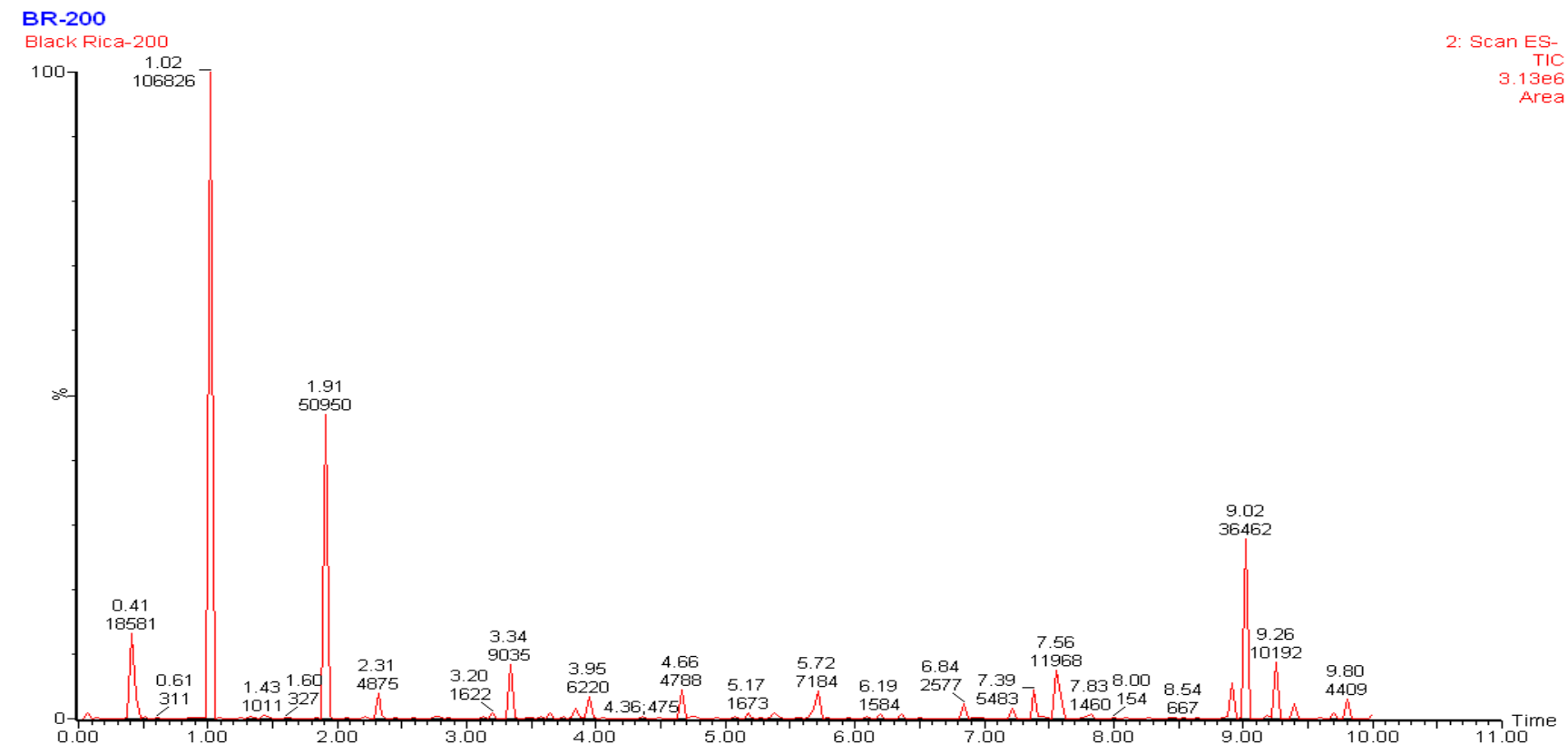

Figure 6. LC-MS chromatogram of $3^{\text {rd }}$ generation of gamma-irradiated black rice BR-200

Table 4. Chemical composition non-irradiated black rice BR-NI by LC-MS

\begin{tabular}{cccl}
\hline No. & $\mathbf{R t}$ & $\mathbf{m} / \mathbf{z}$ & \\
\hline 1 & 0.476 & 185.40 & Methyl-4-hydroxy-3-methoxybenzoate \\
2 & 0.817 & 148.07 & - \\
3 & 1.192 & 778.83 & - \\
4 & 1.634 & 268.22 & Tectochrysin \\
5 & 2.009 & 450.11 & Cyanidin-3-O-glucoside \\
6 & 2.350 & 404.21 & - \\
7 & 2.827 & 126.43 & Thymine \\
8 & 3.099 & 726.57 & - \\
9 & 3.542 & 330.28 & 2 -(3-hydroxy-4-methoxyphenyl)-3,7-dimethoxy-4H-chromen-4-one \\
10 & 3.678 & 933.78 & - \\
11 & 4.398 & 397.22 & Ergosta-4,6,22-trien-3-ol \\
12 & 4.564 & 382.79 & - \\
13 & 4.871 & 797.57 & - \\
14 & 5.177 & 229.00 & Myristic acid \\
15 & 5.348 & 872.67 & - \\
16 & 5.995 & 257.26 & Methyl-9-methyltetradecanoate \\
17 & 6.779 & 925.75 & - \\
18 & 7.119 & 383.45 & - \\
19 & 7.460 & 669.58 & - \\
20 & 7.869 & 120.82 & 4 -vinyl phenol \\
21 & 8.005 & 913.62 & - \\
22 & 8.277 & 729.05 & - \\
23 & 8.618 & 858.68 & - \\
24 & 9.061 & 472.41 & - \\
25 & 9.436 & 112.32 & Heptenal \\
26 & 9.776 & 316.73 & - \\
& & & \\
\hline
\end{tabular}


Table 5. Chemical composition of the $3^{\text {rd }}$ generation of gamma-irradiated black rice BR-200 eluded by LC-MS

\begin{tabular}{cccl}
\hline No. & $\mathbf{R t}$ & $\mathbf{m} / \mathbf{z}$ & \multicolumn{1}{c}{ Compound } \\
\hline 1 & 0.408 & 384.11 & - \\
2 & 0.613 & 296.44 & $3,7,11,15$-tetramethyl-2-hexadecen-1-ol \\
3 & 1.429 & 860.48 & - \\
4 & 1.600 & 408.24 & - \\
5 & 1.906 & 647.18 & - \\
6 & 2.314 & 302.30 & 7 -hydroxy-3-methoxy-2-p-methoxyphenyl-4H-chromen-4-one \\
7 & 3.199 & 759.86 & - \\
8 & 3.335 & 621.60 & - \\
9 & 3.948 & 789.44 & - \\
10 & 4.356 & 464.50 & peonidine-3-O-glucoside \\
11 & 4.663 & 971.05 & - \\
12 & 5.173 & 420.75 & - \\
13 & 5.718 & 167.67 & $4,7,7-$ trimethylbicyclo[3,3,0]octan-2-one \\
14 & 6.194 & 457.57 & - \\
15 & 6.841 & 174.88 & - \\
16 & 7.385 & 118.18 & - \\
17 & 7.555 & 682.72 & - \\
18 & 7.828 & 904.27 & - \\
19 & 7.998 & 574.63 & - \\
20 & 8.542 & 719.73 & - \\
21 & 9.019 & 127.41 & 5 -hydroxymethyl-2-furancarboxaldehyde \\
22 & 9.257 & 926.22 & - \\
23 & 9.802 & 773.69 & - \\
\hline
\end{tabular}

The non-irradiated black rice (BR-NI) has the highest total phenolics and anthocyanins contents. The total phenolics content of BR-200 is higher than that of BR-300, whereas the total anthocyanins contents are lower than that of BR-300. All samples can be categorized as strong antioxidants since all samples have $\mathrm{IC}_{50}$ values less than 50 ppm. Remarkably, both the irradiated black rice have lower $\mathrm{IC}_{50}$ values than that of the non-irradiated black rice. In this case, BR-200 has lower $\mathrm{IC}_{50}$ values than that of BR-300, indicating that the BR-200 has a higher antioxidant activity than the BR-300. Furthermore, the BR-NI and BR-200 were subjected to GC-MS and LC-MS analysis to identify the chemical constituents. The GC spectra of BR-NI and BR-200 revealed 13 and 18 peaks, respectively (Figures 3 and 4$)$. The retardation time $\left(\mathrm{R}_{\mathrm{t}}\right)$ and compounds of BR-NI and BR-200 detected by GC-MS are presented in Table 3. The LC spectra of BR-NI and BR-200 displayed 26 and 23 peaks, respectively (Figures 5 and 6). The retardation time $\left(\mathrm{R}_{\mathrm{t}}\right)$ and mass-to-charge ratio $(\mathrm{m} / \mathrm{z})$ of compounds of BRNI and BR-200 eluded by LC-MS are presented in Tables 3 and 4 , respectively.

\section{Discussion}

The results of GC-MS analysis of BR-NI and BR-200 showed that non-irradiated and gamma-irradiated black rice extracts have the same 4 major components, i.e. hexadecanoic acid; 9,12-octadecadienoic acid; 2-methyl-, 2-(dimethylamino) ethyl ester and cyclohexaneethanamine (Table 3). Several compounds in BR-200 were not detected in BR-NI, which are classified as terpenoids, such as geyrene, caryophyllene, selinene, and cadinene. Decanoic acid was also only be found in BR-200.
The results of LC-MS analysis of BR-NI showed that the identified compounds can be categorized as 1 aliphatic aldehyde (heptanal), 1 aromatic (1-ethyl-3-methylbenzene), 2 simple phenolics (methyl-4-hydroxy-3methoxybenzoate and 4-vinylphenol), 3 flavonoids (tectochrysin, cyanidine-3-O-glucoside and 2-(3-hydroxy4-methoxyphenyl)-3,7-dimethoxy-4H-chromen-4-one) and 1 sterol (ergosta-4,6,22-trien-3-ol). There is pheophytin $a$, chlorophyll $a$ without the $\mathrm{Mg}^{2+}$ ion. The identified compounds of BR-200 can be categorized as 1 aliphatic aldehyde (3,7,11,15-tetramethyl-2-hexadecen-1-ol), 1 furan (5-hydroxymethyl-2-furancarboxaldehyde), 1 macrocycle (bicyclo (4,7,7-trimethylbicyclo[3,3,0]octan-2-one) and 2 flavonoids (7-hydroxy-3-methoxy-2-p-methoxyphenyl-4Hchromen-4-one and peonidine-3-O-glucoside).

Among the identified compounds in BR-NI, the phenolics and flavonoids are responsible for antioxidant activity. Methyl-4-hydroxy-3-methoxybenzoate or methyl vanillate present in cow's milk and beer and are known to have antioxidant activity (Khan 2019). 4-Vinylphenol or 4hydroxy styrene is also found in beer and wine having a hydroxy group at position 4 (Fulcrand, 1996). Tectochrysin is a flavone substituted by a hydroxy group at position 4 and a methoxy group at position 7 respectively. Tectochrysin is a major compound in propolis and has been known to have antioxidant activity that can inhibit the growth of human colon cancer cells (Park at al. 2015). Cyanidin-3-O-glucoside is an anthocyanidin which is a reddish-purple pigment in fruits and vegetables, and as the main pigment in red-colored vegetables and berries (Khoo et al. 2017). It possesses a good antioxidant activity for radical scavenging capacity against superoxide but not hydroxyl radicals (Olivas-Aguirre et al. 2016, Stintzing et 
al. 2002). These findings are in line with previous studies that black rice contains phenolics and flavonoids, including anthocyanins (Apridamayan et al. 2017, Hao et al. 2015).

In BR-200, compounds that may have antioxidant activity are terpenoids, furan, and flavonoids. Geyrene, caryophyllene, selinene, and cadinene are terpenoids that are usually extracted from volatile oils. These terpenoids are known to have good antioxidant activity (Kawaree and Chowwanapoonpoh 2009). 5-hydroxymethylfurfural is a furan which is substituted at positions 2 and 5 by formyl and hydroxymethyl substituents, respectively. It is not found in fresh foods, but it is naturally formed in sugarcontaining foods during drying or cooking (ArribasLorenzo and Morales 2010). It has a hydroxyl group that is responsible for antioxidant activity. 7-Hydroxy-3-methoxy2-p-methoxyphenyl-4H-chromen-4-one is an aromatic heteropolycyclic compound that belongs to the methylated flavonoids, classified as a flavonoid lipid molecule and found in beans. It is also known as a hydroxy flavone and its hydroxyl group is responsible for its antioxidant activity. Peonidin-3-O-glucoside is anthocyanin, a type of flavonoid, which is a natural pigment in fruits and vegetables (Khoo et al. 2017). Several hydroxyl groups present in peonidin-3-O-glucoside, therefore it has powerful antioxidant activities, in terms of the free radical scavenger. It also lowers the metastasis of lung cancer cells and suppresses tumor cell growth (Baea et al. 2015, Jaclyn and Abdel-Aal 2010, Sun et al. 2018).

Non-irradiated and irradiated black rice are categorized as strong antioxidants activity due to the presence of simple phenolics and flavonoids. These compounds can deactivate free radicals due to their ability to donate hydrogen atoms to free radicals. It is noted that $\mathrm{IC}_{50}$ of BR-200 is lower by $32 \%$ compared to the control one, demonstrating that antioxidant activity of irradiated black rice was better than non-irradiated black rice. Surprisingly, phenolic and anthocyanins contents of BR-200 are lower in comparison to BR-NI. Mutation by gamma irradiation has changed the chemical composition of black rice. Although BR-NI and BR-200 have similar metabolite secondary classes, they have different chemical constituents. Gamma-irradiated black rice BR 200 contains peonidin-3-O-glucoside, while BR-NI contains cyanidin-3-O-glucoside. The irradiated black rice BR 200 also contains terpenoids, which are not discovered in BR-NI, that increase its antioxidant activity. In BR-200, the synergistic effect of simple phenolics, flavonoids, and terpenoids improves its antioxidant activity. The irradiation enhanced the antioxidant activity and changed the chemical composition of the nonirradiated black. These findings are in line with previously published results that the mutations change antioxidant activity and chemical contents (Purwanto et al. 2019).

\section{ACKNOWLEDGEMENTS}

The authors thank Sebelas Maret University, Indonesia for funding this research with grant number: 543/UN27.21/PP/2018.

\section{REFERENCES}

Apridamayan P, Prawi R, Purwestri YA, Tunjung WAS, Rumiya. 2017. Anthocyanin, nutrient contents, and an oxidant activity of black rice bran of Oryza sativa L. 'Cempo Ireng' from Sleman, Yogyakarta, Indonesia. Indonesia J Biotechnol 22 (1): 49-54.

Arribas-Lorenzo G, Morales FJ. 2010. Estimation of dietary intake of 5hydroxymethylfurfural and related substances from coffee to Spanish population. Food Chem Toxicol 48 (2): 644-649. DOI: 10.1016/j.fct.2009.11.046.

Baea HS, Kima HJ, Kanga JH, Kudob R, Hosoyab T, Kumazawab S, Juna M, Kima OY, Ahna MR. 2015. Anthocyanin profile and antioxidant activity of various berries cultivated in Korea. Nat Prod Commun 10 (6): 963-968.

Batubara I, Maharni M, Sadiah S. 2017. The potency of white rice (Oryza sativa), black rice (Oryza sativa L. indica), and red rice (Oryza nivara) as antioxidant and tyrosinase inhibitor. J Physics: Conference Series 824: 012017. DOI: 10.1088/1742-6596/824/1/012017.

Bolea C, Turturică M, Stănciuc N, Vizireanu, C. 2016. Thermal degradation kinetics of bioactive compounds from black rice flour (Oryza sativa L.) extracts. J Cereal Sci 71: 160-166. DOI: 10.1016/j.jcs.2016.08.010

Chen XQ, Nagao N, Itani T, Irifune K. 2012. Anti-oxidative analysis, and identification and quantification of anthocyanin pigments in different coloured rice. Food Chem 135 (4): 2783-2788. DOI: 10.1016/j.foodchem.2012.06.098.

Cisowska A, Wojnicz D, Hendrich AB. 2011. Anthocyanins as antimicrobial agents of natural plant origin. Nat Prod Commun 6 (1): $149-156$.

Doymaz I, Karasu S. 2018. Effect of air temperature on drying kinetics, colour changes and total phenolic content of sage leaves (Salvia officinalis). Qual Assur Saf Crops Foods 10 (3): 269-276. DOI: 10.3920/QAS2017.1257

El-Degwy IS. 2013. Mutation induced genetic variability in rice (Oryza sativa L.). Egypt J Agron 35 (2): 199-209.

Fulcrand H, dos Santos P-JC, Sarni-Manchado P, Cheynier V, FavreBonvin J. 1996. Structure of new anthocyanin-derived wine pigments. J Chem Soc Perkin Trans 1 (7): 735-739.

Hao J, Zhu H, Zhang Z, Yang S, Li H. 2015. Identification of anthocyanins in black rice (Oryza sativa $L$.) by UPLC/Q-TOF-MS and their in vitro and in vivo antioxidant activities. J Cereal Sci 64: 92-99. DOI: 10.1016/j.jcs.2015.05.003

Harding SS, Johnson SD, Taylor DR, Dixon CA, Turay MY. 2012. Effect of gamma rays on seed germination, seedling height, survival percentage and tiller production in some rice varieties cultivated in Sierra Leone. Am J Exp Agric 2 (2): 247-255.

Hartanti RS, Putri TAN, Zulfa F, Sutarno, Suranto. 2017. Identification of morphological character and esterase isozyme pattern in secondgeneration black rice plant irradiated to gamma rays. IOP Conf Ser Mater Sci Eng 193: 012038. DOI: 10.1088/1757-899X/193/1/012038.

He J, Giusti MM. 2010. Anthocyanins: natural colorants with healthpromoting properties. Ann Rev Food Sci Technol 1: 163-187.

Hou Z, Qin P, Zhang Y, Cui S, Ren G. 2013. Identification of anthocyanins isolated from black rice (Oryza sativa L.) and their degradation kinetics. Food Res Int 50: 691-697.

Hu C, Zawistowski J, Ling W, Kitts DD. 2003. Black rice (Oryza sativa L. indica) pigmented fraction suppresses both reactive oxygen species and nitric oxide in chemical and biological model systems. J Agric Food Chem 51 (18): 5271-5277. DOI: 10.1021/jf034466n.

Kawaree R, Chowwanapoonpoh S. 2009. Stability of chemical components and antioxidant activity of volatile oils from some medicinal plants in Thailand. J Nat Sci 8 (1): 23-35.

Khan IT, Bule M, Ullah R, Nadeem M, Asif S, Niaz K. 2019. The antioxidant components of milk and their role in processing, ripening, and storage: Functional food. Vet World 12 (1): 12-33. DOI: 10.14202/vetworld.2019.12-33.

Khoo HE, Azlan A, Tang ST, Lim SM. 2017. Anthocyanidins and anthocyanins: Colored pigments as food, pharmaceutical ingredients, and the potential health benefits. Food Nutr Res 61 (1): 1361779. DOI: $10.1080 / 16546628.2017 .1361779$.

Lee JH. 2010. Identification and quantification of anthocyanins from the grains of black rice (Oryza sativa l.) varieties. Food Sci Biotechnol 19: 391-397. DOI: 10.1007/s10068-010-0055-5.

Loypimai P, Moongngarm A, Chottanom P. 2016. Thermal and $\mathrm{pH}$ degradation kinetics of anthocyanins in natural food colorant prepared 
from black rice bran. Food Sci Technol 53 (1): 461-470. DOI: 10.1007/s13197-015-2002-1.

Marcu D, Damian G, Cosma C, Cristea V. 2013. Gamma radiation effects on seed germination, growth and pigment content, and ESR Study of induced free radicals in maize (Zea Mays). J Biol Phys 39 (4): 625634. DOI: 10.1007/s10867-013-9322-z.

Olivas-Aguirre FJ, Rodrigo-García J, Martínez-Ruiz NR, CárdenasRobles AI, Mendoza-Díaz SO, Álvarez-Parrilla E, González-Aguilar GA, Rosa LA, Ramos-Jiménez A, Wall-Medrano A. 2016. Cyanidin3-O-glucoside: Physical-chemistry, foodomics and health effects. Molecules 21 (9): 1264. DOI: 10.3390/molecules21091264.

Park MH, Hong JE, Park ES, Yoon HS, Seo DW, Hyun BK, Han SB, Ham YW, Hwang BY, Hong JT. 2015. Anticancer effect of tectochrysin in colon cancer cell via suppression of NF-kappaB activity and enhancement of death receptor expression. Mol Cancer 14: 124. DOI: $10.1186 / \mathrm{s} 12943-015-0377-2$.

Park YS, Kim SJ, Chang HI. 2008. Isolation of anthocyanin from black rice (Heugjinjubyeo) and screening of its antioxidant activities. J Microbiol Biotechnol 36: 55-60.

Patmi YS, Pitoyo A, Solichatun, Sutarno. 2020. Effect of drought stress on morphological, anatomical, and physiological characteristics of Cempo Ireng cultivar mutant rice (Oryza sativa L.) strain 51 irradiated by gamma-ray. J Physics: Conf Ser 1436: 012015. DOI: 10.1088/1742-6596/1436/1/012015.

Pratiwi R, Purwestri YA. 2017. Black rice as a functional food in Indonesia. Funct Foods Health Dis 7 (3): 182-194.

Pratiwi R, Tunjung WAS, Rumiyati R, Amalia AR. 2015. Black rice bran extracts and fractions containing cyanidin 3 -glucoside and peonidin3 -glucoside induce apoptosis in human cervical cancer cells. Indonesia J Biotechnol 20 (1): 69-76.

Purwanto E, Nandariyah, Yuwono SS, Yunindanova MB. 2019. Induced mutation for genetic improvement in black rice using gamma-ray. Agrivita J Agric Sci 41 (2): 213-220.

Rathna Priya TS, Nelson ARLE, Ravichandran K, Antony U. 2019 Nutritional and functional properties of coloured rice varieties of South India: A review. J Ethnic Foods 6: 11. DOI: 10.1186/s42779019-0017-3.

Riyatun, Suharyana, Ramelan AH, Sutarno, Saputra OA, Suryanti V. 2018. Proximate nutritional evaluation of gamma-irradiated black rice (Oryza sativa L. cv. Cempo Ireng). IOP Conf Ser Mater Sci Eng 333 012073. DOI: 10.1088/1757-899X/333/1/012073.
Rukmana RM, Soesilo NP, Rumiyati, Pratiwi R. 2016. The effect of ethanolic extract of black and white rice bran (Oryza sativa 1.) on cancer cells. Indonesia J Biotechnol 21(1): 63-69.

Salazar-Aranda R, Perez-Lopez LA, Lopez-Arroyo, Alanis-Garza BA, de Torres NW. 2011. Antimicrobial and antioxidant activities of plants from Northeast of Mexico. Evid-Based Compl Alt Med 2011: 536139. DOI: 10.1093/ecam/nep127.

Seo WD, Kim JY, Han SI, Ra JE, Lee JH, Song YC, Park MJ, Kang HW, Oh SK, Jang KC. 2011. Relationship of radical scavenging activities and anthocyanin contents in the 12 colored rice varieties in Korea. J Korean Soc Appl Biol Chem 54: 693-699. DOI: 10.1007/BF03253147.

Shao Y, Tang F, Xu F, Wang Y, Bao J. 2013. Effects of $\gamma$-irradiation on phenolics content, antioxidant activity and physicochemical properties of whole grain rice. Radiation Physics Chem 85: 227-233. DOI: 10.1016/j.radphyschem.2013.01.022

Shipp J and Abdel-Aal E-SM. 2010. Food applications and physiological effects of anthocyanins as functional food ingredients. Open Food Sci J 4: 7-22.

Stintzing FC, Stintzing AS, Carle R, Frei B, Wrolstad RE. 2002. Color and antioxidant properties of cyanidin-based anthocyanin pigments. J Agric Food Chem 50 (21): 6172-6181. DOI: 10.1021/jf0204811.

Sun H, Zhang P, Zhu Y, Lou O, He S. 2018. Antioxidant and prebiotic activity of five peonidin-based anthocyanins extracted from purple sweet potato (Ipomoea batatas (L.) Lam.). Sci Rep 8 (1): 5018. DOI: 10.1038/s41598-018-23397-0.

Suryanti S, Kusumaningsih T, Marliyana SD, Setyono HA, Trisnawati EW. 2020. Identification of active compounds and antioxidant activity of teak (Tectona grandis) leaves. Biodiversitas 21 (3): 946952. DOI: $10.13057 / \mathrm{biodiv} / \mathrm{d} 210313$.

Suttiarporn P, Sookwong P, Mahatheeranont S. 2016. Fractionation and identification of antioxidant compounds from bran of Thai black rice cv. riceberry. Intl J Chem Eng Appl 7 (2): 109-114. DOI: 10.7763/IJCEA.2016.V7.552

Walter M, Marchesan E. 2011. Phenolic compounds and antioxidant activity of rice. Brazilian Archiv Biol Technol 54: 371-377.

Zhang MW, Zhang RF, Zhang FX, Liu RH. 2010. Phenolic profiles and antioxidant activity of black rice bran of different commercially available varieties. J Agric Food Chem 58: 7580-7587. 